\title{
Evaluation of the pregnant women referred for dermatology consultation
}

\section{Dermatoloji konsültasyonu istenen gebelerin değerlendirilmesi}

\author{
Atiye OĞRUM, Zennure TAKCI, Havva Yıldız SEÇKiN
}

ABSTRACT

Pregnancy is a physiological state that is associated with various physiological skin changes and specific dermatoses. The purpose of this study was to evaluate the dermatologic problems of pregnants followed by obstetrics and gynecology clinic by analyzing dermatology consultations, retrospectively. The data, including dermatology consultations requested by obstetrics and gynecology clinic for pregnants between September 2011-May 2017 were screened. Sixty-one patients without any missing information were included in the study. The mean age of 61 cases was $30.66 \pm 6.61$ years (19-43 years). Their gestational weeks varied between 5, and 40 weeks and 29 patients (47.5\%) were primigravid, 32 patients (\%52.5) multigravid and five patients (\%8.2) were in postpartum period. The reason for asking consultations for two pregnants was the physiological change of pregnancy. Sixteen patients (26.2\%) had pregnancy-specific dermatosis; 11 patients diagnosed with polymorphic eruption of pregnancy, four patients with intrahepatic cholestasis of pregnancy and one patient had pemphigoid gestationis. The pregnants with the diagnosis of gestational dermatosis were in their third trimesters $(n=14)$ or postpartum periods. Forty-five pregnant patients or those in their postpartum period for whom consultations were requested (75\%) had itching with or without a rash. There were three pregnant women who used drugs in the $C, D$ and $X$ pregnancy categories for consultation because of unplanned pregnancy and drug use. Pruritis was detected as the most frequent complaint. Infection and drug use that could affect maternal and infant health were attracting attention among the reasons for consultation request.

Keywords: Pregnant, pregnancy, dermatology, consultation

\section{Giriş}

Gebelik, karmaşık hormonal, immünolojik, metabolik, vasküler ve psikolojik değişikliklerin olduğu ve her an anneye fetüs için acil müdahale gerektirebilecek durumların ortaya çıkabileceği fizyolojik bir dönem$\mathrm{dir}^{1}$. Bu süreçte deride ortaya çıkan değişiklikler anne adaylarında kadın hastalıkları ve doğum ya da dermatoloji uzman kontrolüne gereksinim hissettirebilir.
Öz

Gebelik çeşitli fizyolojik deri değişiklikleri ve spesifik dermatozların eşlik ettiği fizyolojik bir durumdur. Bu çalışmanın amacı, kadın hastalıkları ve doğum kliniği tarafından takip edilen gebelerin dermatoloji konsültasyonlarını retrospektif olarak inceleyerek dermatolojik sorunları değerlendirmektir. Eylül 2011-Mayıs 2017 tarihleri arasında kadın hastalıkları ve doğum kliniği tarafından dermatoloji konsültasyonu istenen gebe kadınlara ait veriler retrospektif olarak tarandı. Verilerinde eksiklik saptanmayan 61 hasta çalışmaya dahil edildi. Yaşları 19-43 arasında değişen 61 olgunun yaş ortalaması 30,66 66,61 yıl idi. Gebelik haftaları 5-40 hafta arasında değişen gebelerin 29 'u $(\% 47,5)$ primigravid, 32'si $(\% 52,5)$ multigravid olup, beş hasta $(\% 8,2)$ postpartum dönemdeydi. Iki gebede konsültasyon istenme nedeni gebeliğin fizyolojik değişikliğiydi. On altı hastada $(\% 26,2)$ gebeliğe özgü dermatoz mevcut olup, bunlardan 11'i gebeliğin polimorf erüpsiyonu, dördü gebeliğin intrahepatik kolestazı ve biri pemfigoid gestasyonis tanısı aldı. Gebeliğe özgü dermatoz tanısı alan gebelerin 14'ü üçüncü trimestırda, ikisi postpartum dönemde idi. Konsültasyon istemi yapılan gebe ve postpartum dönemdeki kadınların 45'inde (\%75) kaşıntı veya kaşıntının eşlik ettiği döküntü mevcuttu. Plansız gebelik ve ilaç kullanımı nedeniyle konsültasyon istemi yapılan $C, D$ ve $X$ gebelik kategorisinde ilaç kullanan üç gebe mevcuttu. Konsültasyon istemi yapılan gebelerdeki en sık yakınma kaşıntıydı. Anne ve bebek sağlığını etkileyebilecek enfeksiyon ve ilaç kulIanımı konsültasyon istem nedenleri arasında dikkat çekiciydi.

Received: 21.07 .2017

Accepted: 14.08 .2017

Department of Dermatology and Venereology, Gaziosmanpasa University, Tokat

Yazışma adresi: Atiye Oğrum, Gaziosmanpaşa Üniversitesi, Tıp Fakültesi, Deri ve Zührevi Hastalıkları Anabilim Dalı, Tokat, Turkey

e-mail: aogrum@yahoo.com

Burada, kadın hastalıkları ve doğum kliniğinden dermatolojiye konsülte edilen gebe ve postpartum dönemdeki kadınların yakınmalarının değerlendirilmesi amaçlandı.

\section{GEREÇ ve YÖNTEM}

17-KAEK-065'nolu Etik Kurul onayı sonrası, Eylül 2011 ile Mayıs 2017 tarihleri arasında Gaziosmanpaşa 
Üniversitesi Araştırma ve Uygulama Hastanesi Kadın Hastalıkları ve Doğum Kliniğinde takip edilen ve dermatoloji konsültasyonu istenen 18 yaş üstü gebe ve postpartum dönemdeki kadınların dosyaları retrospektif olarak incelendi. Hastalara ait demografik veriler ve dermatolojik yakınmalar (yaş, gebelik sayısı, konsültasyon tarihindeki gebelik haftası, trimestır, Dermatoloji Kliniğinde alınan tanı) kaydedildi.

Verilerin analizinde tanımlayıc istatistik yöntemleri kullanıldı. Tüm analizler Statitical Package for Social Sciences (SPSS Inc, Chi, IL) version 20 programı ile gerçekleştirildi.

\section{BULGULAR}

Çalışmada yaşları 19-43 arasında olan 61 gebe mevcuttu. Gebelerin 29'u $(\% 47,5)$ primigravid, 32'si $(\% 52,5)$ multigravid olup, yaş ortalamaları $30,66 \pm 6,61$ yıl idi. Gebelik haftası 5-40 hafta arasında değişmekte olup, beş hasta $(\% 8,2)$ postpartum dönemin ilk üç günündeydi. Gebelerin 9'u $(\% 14,8)$ birinci trimestır, $19^{\prime}$ u $(\% 31,1)$ ikinci trimestır, $28^{\prime} i(\% 45,9)$ ise üçüncü trimestırdaydı.

Konsülte edilen gebelerin ikisinde $(\% 3,3)$ gebeliğin fizyolojik değişikliği, 16 'sında $(\% 26,2)$ gebeliğe özgü dermatoz (GÖD), 43'ünde $(\% 70,5)$ ise gebeliğe özgü olmayan hastalıklar (GÖOH) vardı.

Hastalık gruplarına bakılmaksızın gebelerin $45^{\prime}$ inde (\%75) kaşıntı veya kaşıntının eşlik ettiği döküntü yakınması mevcuttu. Gebeliğin fizyolojik değişikliklerinden olan stria gravidarum nedeniyle konsültasyon istemi yapılan hastanın ikiz gebeliği mevcuttu. Klitoris inferiorunda yerleşen mor kitlenin değerlendirilmesi ve ek öneri açısından konsültasyon istenen üçüncü trimestırdaki gebede vajinal mukozal rugalarda belirginleşme ve venöz staza bağlı değişiklik saptandı (Figür 1a ve b).

GÖD saptanan 16 gebenin 11 'inde gebeliğin polimorf erüpsiyonu (GPE) mevcuttu. Bunlardan birinin konsültasyon istem nedeni, kaşıntının doğum için endikasyon oluşturup oluşturmadığı ve yararına dair



a

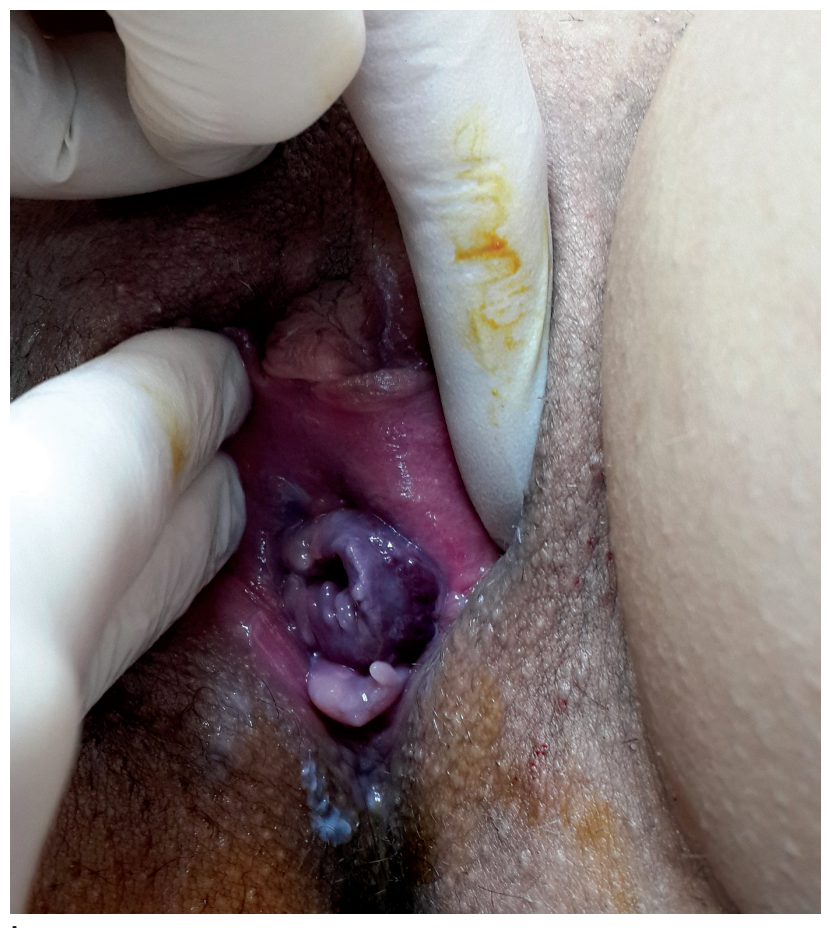

b

Figür 1. Klitoris inferiorunda iki adet mor ve mukoza renginde nodüler lezyonlar (a), ayrıntılı incelemede ödemli mor renkte himen ve inferiorunda lokalize deri renginde himen parçası (b).

görüş almak iken, postpartum iki hastanın ise kaşıntıya yönelik ek öneri alma amaçlıydı. Kaşıntı yakınma- 
Sı olan dört gebede gebeliğin intrahepatik kolestazı (GIK), bir gebede pemfigoid gestasyonis (PG) saptandı. (Figür 2). GÖD saptanan hastaların trimestıra göre dağılımı Tablo 1'de verilmiştir.

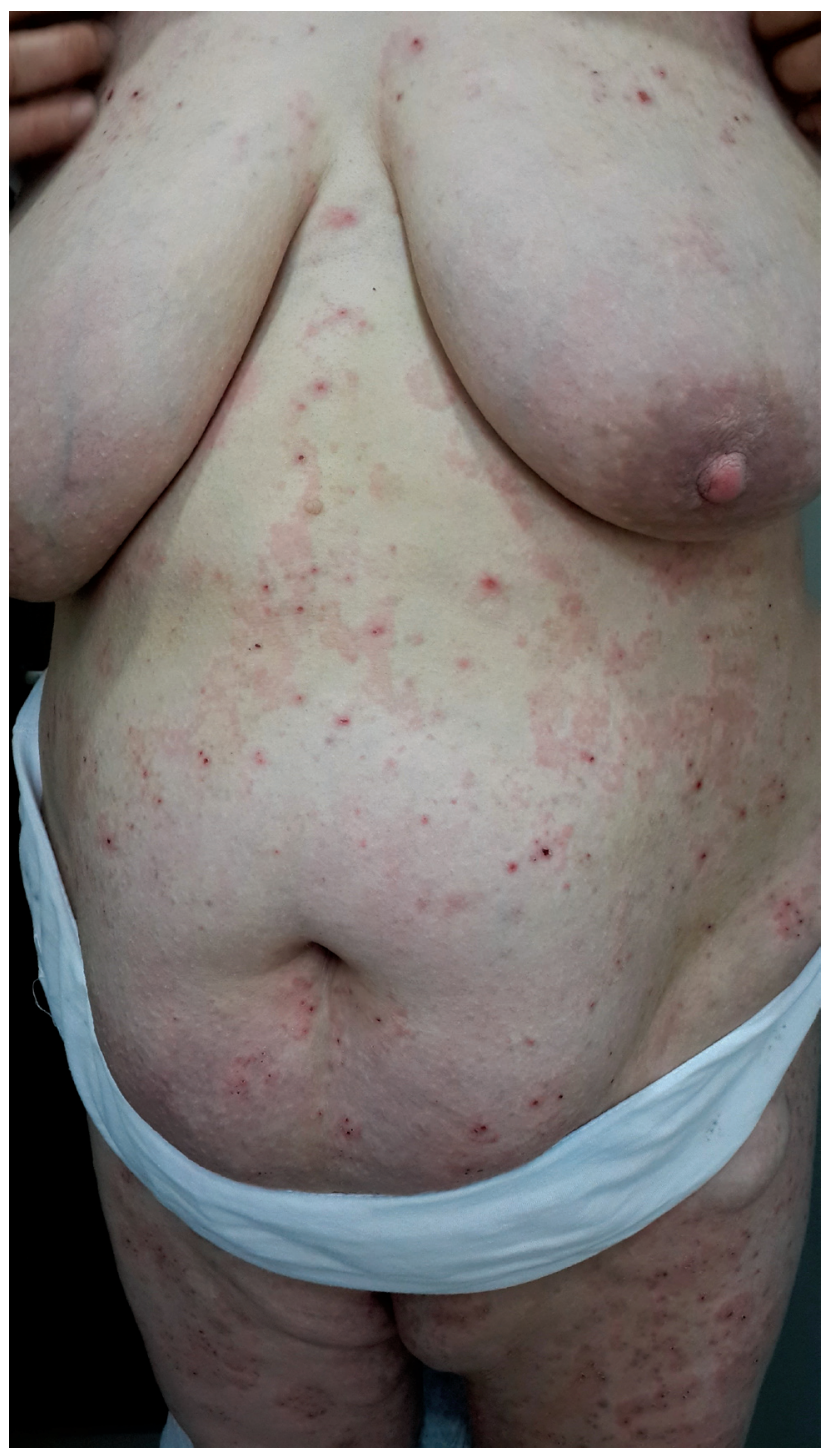

Figür 2. Vücutta yaygın ürtikeryal plak ve ekskoriasyonlar.

Gebeliğe özgü olmayan dermatoz grubundaki 43 hastadan onunda konsültasyon istem nedeni enfeksiyon olup, bunlar; viral (altı hasta), paraziter (bir hasta), fungal enfeksiyon (üç hasta) idi. Varisella tanısıyla konsültasyon istemi yapılan hastanın doğum öncesi enfeksiyon hastalıkları kliniğine, doğum sonrası dermatoloji kliniğine danışıldığı saptandı. Konsültasyon istem nedeni genital verrü olan gebeler ikinci ve üçüncü trimestırdaydı. GÖOH grubundaki 20 hastada dermatoz gözlenmiş olup, pruritus, ürtiker ve kontakt dermatit sırasıyla en sık saptanan dermatozlar olarak belirlendi. İlaç kullanımı ve plansız gebelik nedeniyle konsültasyon istemi yapılan hastalar sistemik steroid ve azatiopirin kullanan Behçet hastası; isotretinoin kullanan akne hastası ve omalizumab tedavisi alan kronik ürtiker hastasıydı. Üç Behçet hastasından ikisinin konsültasyon istem nedeni genital ülserdi. GÖOH'ların trimestır ve postpartum döneme göre dağılımı Tablo 2'de verilmiştir.

Tablo 1. Gebeliğe özgü dermatozların trimester ve postpartum döneme göre dağılımı.

\begin{tabular}{llllll}
\hline GÖD & $\begin{array}{l}\text { Birinci } \\
\text { trimestır }\end{array}$ & $\begin{array}{l}\text { ikinci } \\
\text { trimestir }\end{array}$ & $\begin{array}{l}\text { Üçüncü } \\
\text { trimestir }\end{array}$ & Postpartum & Toplam \\
\hline GPE & 0 & 0 & 9 & 2 & 11 \\
GiK & 0 & 0 & 4 & 0 & 4 \\
P & 0 & 0 & 1 & 0 & 1 \\
Toplam & 0 & 0 & 14 & 2 & 16 \\
\hline
\end{tabular}

GÖD: Gebeliğe Özgü Dermatoz, GPE: Gebeliğin polimorf erüpsiyonu, GiK: Gebeliğin intrahepatik kolestazı, PG: Pemfigoid gestasyonis.

\section{TARTIŞMA}

Gebelik karmaşık homonal, immünolojik, metabolik süreçlerin etkisiyle çok sayıda değişikliğin gözlendiği bir dönemdir ${ }^{2-4}$. Bu değişiklikler temelde gebeliğin fizyolojik değişiklikleri, GÖD ve GÖOH olarak sınıflandırılabilir.

Gebeliğin fizyolojik değişiklikleri; pigmentasyon değişiklikleri, bağ dokusu değişiklikleri, vasküler, pilosebase ünite, tırnak ve glandüler aktivite değişiklikleri olarak sınıflandırılabilir ${ }^{5-7}$. Stria gravidarum, kloasma, tırnak değişiklikleri, diş eti değişiklikleri dermatoloji polikliniğine müracat eden gebelerde sık saptanan bulgular olarak bildirilmiştir ${ }^{3,8,9}$. Fizyolojik değişiklik nedeniyle konsülte edilen gebe sayısının azlığı ve bunların primigravid oluşu, bu yakınmaların gebeleri direk olarak dermatolojiye yönlendirdiği ve ya uzman kontrolüne gereksinim hissettirmediğini düşündürdü.

GÖD'lar; GPE, GiK, PG ve gebeliğin atopik erüpsiyonunu içeren bir grup hastalık olup, çoğunlukla ikinci ve üçüncü trimestırda ortaya çıkar ${ }^{5,10}$. GÖD tanılı 
Tablo 2. Gebeliğe özgü olmayan hastalıkların trimestır ve postpartum döneme göre dağılımı.

\begin{tabular}{|c|c|c|c|c|c|c|}
\hline Hastalık grubu & Tanı & Birinci tr & İkinci tr & Üçüncü tr & Postpartum & Toplam \\
\hline \multirow[t]{6}{*}{ Viral enfeksiyonlar } & Zona & 0 & 0 & 1 & 0 & 1 \\
\hline & Kızamık & 1 & 0 & 0 & 0 & 1 \\
\hline & Herpes labialis & 0 & 0 & 1 & 0 & 1 \\
\hline & Varisella & 0 & 0 & 0 & 1 & 1 \\
\hline & Genital verrü & 0 & 1 & 1 & 0 & 2 \\
\hline & Skabiyez & 0 & 0 & 1 & 0 & 1 \\
\hline Paraziter enfeksiyonlar & Tinea pedis & 0 & 1 & 1 & 0 & 2 \\
\hline \multirow[t]{2}{*}{ Fungal enfeksiyonlar } & Vajinal kandidiazis & 0 & 1 & 0 & 0 & 1 \\
\hline & Ürtiker & 2 & 1 & 0 & 0 & 3 \\
\hline \multirow[t]{3}{*}{ Dermatozlar } & Prurigo simpleks & 0 & 7 & 7 & 1 & 15 \\
\hline & Kontakt dermatit & 0 & 2 & 0 & 0 & 2 \\
\hline & Behçet hastalığı & $3^{*}$ & 0 & 0 & 0 & 3 \\
\hline \multirow[t]{8}{*}{ Diğer } & Nörofibromatozis & 0 & 1 & 0 & 0 & 1 \\
\hline & Vestibüler papillomatozis & 0 & 0 & 1 & 0 & 1 \\
\hline & Böcek ısırığı & 0 & 1 & 0 & 0 & 1 \\
\hline & Eritema multiforme & 0 & 1 & 0 & 0 & 1 \\
\hline & Pitriazis rozea & 0 & 1 & 0 & 0 & 1 \\
\hline & Akne & 1 & 1 & 0 & 0 & 2 \\
\hline & İlaç ve plansız gebelik & 2 & 0 & 0 & 0 & 2 \\
\hline & Epidermoid kist & 0 & 0 & 0 & 1 & 1 \\
\hline Toplam & & 9 & 18 & 13 & 3 & 43 \\
\hline
\end{tabular}

tr: trimestir

*: Hastalardan biri ilaç kullanımı ve plansız gebelik nedeniyle danışıldı.

hastaların üçüncü trimestırda olması literatürle uyumluydu ${ }^{5,11,12}$. GPE'nin primigravidlerde, çoğul gebelik ve kilolu bebek varlığında daha sık görüldüğü bildirilmiştir ${ }^{12-14}$. Çalışmaya dahil olan 11 GPE tanılı hastanın altısı primigravid ve birinde çoğul gebelik mevcut olup, literatürle uyumludur. Kaşıntı nedeniyle konsültasyon istemi yapılan iki GÖD tanılı hastanın postpartum dönemde olması, ayrıca bir gebenin konsültasyon istem nedeninin doğum endikasyonu açısından değerlendirme amaçlı oluşu, yaşam kalitesini etkileyen kaşıntının ihmal edilemez şiddette de olabileceğini düşündürdü. Ayrıca GPE tanılı hastalarda kaşıntıyı gidermek amaçlı doğum planlanmasının kaşıntıya yarar sağlamadığı yönündeki görüş ağılıklıdır 5 .

Varisella saptanan hastanın enfeksiyon hastalıkları tarafından tedavi verilmekle beraber, dermatoloji görüşü de istenmesi, yapılacak müdahalenin iki bireyin sağlığını etkileyeceği düşüncesiyle sağlık çalışanlarının da daha kontrollü ve temkinli bir yaklaşım sergilediğini gösteriyor olabilir. Genital verrü nedeniyle konsültasyon istemi yapılan gebelerin ikinci ve üçüncü trimestırda olması, doğuma hazırlık süresinde vajinal bölgenin temizlenmesinde gebeye zararı olmayan ve anestezisiz uygulanabilen kriyoterapi gibi bir tedavi alternatifini kullanma isteğiyle ilgili olabilir.

Gebeliğe özgü olmayan hastalık grubunda en yüksek oranda saptanan konsültasyon istem nedeni prurigo simpleks olup, literatür ile uyumluydu, ${ }^{9,15}$. Ayrıca gebelerin 45'inde (\%75) kaşıntı ya da kaşıntının eşlik ettiği döküntü yakınmasının olması kaşıntının hem kadın hastalıkları ve doğum hem de dermatoloji kliniklerine başvuruda önemli bir neden olduğunu göstermektedir.

Kaşıntıyla seyreden gebelik dermatozlarının birçoğunda topikal nemlendiriciler ile semptomatik rahatlama sağlanabilir ${ }^{17}$. Bu nedenle ilk ve en güvenilir yaklaşım emolyenler ile deri kuruluğunun azaltılması ve deri bariyerinin güçlendirilmesidir. Emolyenler ile rahatlama sağlanamaması durumunda, ilk trimestır sonrası olmak üzere topikal kortikosteroidler, sedasyon gerekliliği değerlendirilerek gebelik kategorisi B olan sedatif (klorfeniramin, siproheptadin) ya da nonsedatif antihistaminikler (setirizin, levosetirizin, 
loratadin) ve şiddetli vakalarda kısa süreli sistemik kortikosteroid tedavisi alternatifler arasındadır. Nemlendirici kullanımı ile yakınmaları gerilemeyen olgularımızda oral antihistaminik, topikal ve kısa süreli sistemik kortikosteroid tedavileri uygulanmıştır. PG tanılı hastanın sistemik kortikosteroid dozu postpartum alevlenme nedeniyle artırılmış ve uzun dönem tedavi uygulanmıştır.

İlaç kullanımı ve plansız gebelik nedeniyle konsültasyon istemi yapılan üç hasta olması ve hasta sayısı az olmakla beraber, kullanılan ilaçların riskli kategorisi, toplumun ve özelikle kadınların güvenilir doğum kontrol yöntemi kullanımına yönelik bilinç düzeyinin artırılması gerektiğini düşündürmektedir.

Bu çalışmanın önemli bazı kısıtıııkları vardır:

1-Aynı tarih aralığında dermatolojik şikayet ile direkt dermatoloji polikliniğine başvuran gebe hastaların oranı,

2-Kadın hastalıkları ve doğum polikliniğine gelen gebelerin yüzde kaçında dermatolojik yakınma olduğu ve bunların ne kadarının dermatoloji polikliniklerine konsültasyon istemiyle yönlendirildiğine dair verilere ulaşılamaması nedeni ile dermatolojik yakınmaların hasta ve hekim tarafından ne kadar ciddiye alındığı belirlenememiştir.

Sonuç olarak, gebelerin konsültasyon istemiyle dermatoloji kliniklerine yönlendirilmesinin en sık nedeni kaşıntı yakınmasına yönelik semptomatik tedavidir. Emolyenlerle yakınmasında gerileme gözlenmeyen hastalara sedatif ve nonsedatif antihistaminikler, topikal kortikosteroidler ve şiddetli ya da dirençli olgulara sistemik kortikosteroid tedavileri uygulanmıştır. Ayrıca gebelikte ortaya çıkan ve anne ya da bebek sağlığını etkileyebilen enfeksiyon ya da ilaç kullanımı durumları da konsültasyon istenme nedenlerindendir.

\section{KAYNAKLAR}

1. Yılmaz Doğru H, Oktay G, Özsoy AZ, ve ark. Acil Servise Başvuran Gebelerin Değerlendirilmesi: Üçüncü Basamak Tek Merkez Deneyimi. Van Tıp Derg 2017;24:157-162.

2. Pãunescu $M M$, Feier $V$, Pãunescu $M$, et al. Dermatoses of pregnancy. Acta Dermatovenerol Alp Pannonica Adriat 2008;17:4-11.

3. Sumit K, Ajay K, Varma SP. Pregnancy and skin. J Obstet Gynecol India 2012;62(3):268-275.

https://doi.org/10.1007/s13224-012-0179-z

4. Ambros-Rudolph CM. Disorders of pregnancy. In: Burgdorf WH, Plewig G, Wolff HH, Landthaler M, editors. Braun-Falco's Dermatology. $3^{\text {rd }}$ ed. Heidelberg: Springer Medizin Verlag; 2009. p. 1160-1169.

https://doi.org/10.1007/978-3-540-29316-3_77

5. İnan Yüksel E, Turgut Erdemir A, Turan E, ve ark. Gebeliğe özgü dermatozlar ve tedavileri. Istanbul Med J 2011;12:3035.

6. Bolanca I, Bolanca Z, Kuna K, et al. Chloasma--the mask of pregnancy. Coll Antropol 2008;32(Suppl 2):139-141.

7. Barankin B, Silver SG, Carruthers A. The skin in pregnancy. J Cutan Med Surg 2002;6:236-240. https://doi.org/10.1007/s10227-001-0045-6

8. Bakar Dertlioğlu S, Çiçek D, Uçak H, ve ark. Gebelikte gözlenen deri değişiklikleri ve gebelik dermatozlarının incelenmesi. Firat Tıp Dergisi 2011;16:170-174.

9. Çınar SL, Kartal D, Uludağ SZ, et al. The skin findings of pregnant women and our treatment choices. A Turkish experience: A 5-year survey. Kafkas J Med Sci 2016;6:46-52. https://doi.org/10.5505/kjms.2016.93063

10. Chander R, Garg T, Kakkar S, Jain A. Specific pregnancy dermatoses in 1430 females from Northern India. J Dermatol Case Rep 2011;5:69-73. https://doi.org/10.3315/jdcr.2011.1080

11. Chaudhary R, Mahakal N, Chauhan A, Modi K. Dermatological disorders in pregnancy: a cross-sectional study. Int J of Scientific Study 2015;3:118-122.

12. Kroumpouzos G, Cohen LM. Specific dermatoses of pregnancy: an evidence-based systematic review. Am J Obstet Gynecol 2003;188:1083-1092. https://doi.org/10.1067/mob.2003.129

13. Coşkun B, Öztürk P, Çiçek D. Gebelik dermatozları. Dermatose 2004;3:72-76.

14. Polat M, Dönmez ME. Gebelik dermatozları. Türk Jinekoloji ve Obstetrik Derneği Dergisi 2008;5:241-247.

15. Wong RC, Ellis CN. Physiologic skin changes in pregnancy. J Am Acad Dermatol 1984;10:929-940. https://doi.org/10.1016/S0190-9622(84)80305-9

16. Shanmugam S, Thappa DM, Habeebullah S. Pruritus gravidarum: a clinical and laboratory study. J Dermatol 1998;25:582586. https://doi.org/10.1111/j.1346-8138.1998.tb02462.x

17. Teixeira V, Coutinho I, Gameiro R, et al. Specific dermatoses of pregnancy. Acta Medica Portuguesa 2013;26:593-600. 